\title{
Self-Regulated Learning Differences between Obese and Non-Obese Adolescents: A Comparative Study of Senior High School Students in Medan City
}

\author{
${ }^{1}$ Fasti Rola, ${ }^{2}$ Ade Rahmawati Srg, ${ }^{3}$ Debby A. Daulay \\ 1Fakultas Psikologi Departement of Educational Psychology \\ 2,3Fakultas Psikologi Departement of Developmental Psychology \\ University of Sumatera Utara \\ Medan, Indonesia \\ E-mail: ade.rahmawati@usu.ac.id
}

\begin{abstract}
This study examined the differences in self-regulated learning of obese and non-obese adolescents. The sample was 234 senior high school students in Medan City, equally distributed, with 117 of them were obese, and 117 were normal weight students. Data was gathered using self-regulated learning scale constructed by researchers utilized Zimmerman`s self-regulation strategies in learning (in Schunk \& Zimmerman, 1998). Afterward, the data were analyzed using independent t-test. The results found that there were no self-regulated learning differences between obese and non-obese students.
\end{abstract}

Keyword: Self-Regulated Learning, Obese Adolescents

\section{INTRODUCTION}

Learning is a never-ending activity and happens throughout life. Humans always face changes and often have to learn various ways to adapt to be an excellent individual (LPTUI Team, 2005). As defined, learning is a process in which behavior is generated or changed through practices or experiences. Watkins (in Savitri, 2008) believed that learning is an active process to get a better understanding of the worlds based on knowledge.

Formally, learning process happens in schools. For teenagers, most of them is a student at the senior high school. School is believed as a place to develop students' cognitive, affective, as well as psychomotor skills. It is expected to produce intelligent, creative, skillful, and responsible young generation (Savira \& Suharsono, 2013). About adolescent, Piaget (in Santrock, 2013) described adolescence as a period of cognitive development that has reached formal operation stage. Therefore, high school student activities are the result of logical thinking. Also, their affective and moral development has also developed and is expected to support their academic tasks. This opinion pointed out that high school students are considered to have a responsibility to complete their academic tasks (Savira \& Suharsono, 2013).

On the other hand, adolescence is a period of change, and the most observable change is physical changes. Therefore, most of the teenagers become anxious about their body shape and appearance. This is in line with Hurlock (2010) that said, adolescence is a period of attention to physical development, appearance, peers, and the opposite sex.

Also, adolescent's views of physical change depend on their environment as well as their-self (Monks, 1999). Positive feedback from the environment may trigger teenagers to develop their potential better. One effort to overcome their potential is by learning independently, called self-regulated learning. Zimmerman (in Woolfolk, 2004) argued that self-regulation be a process where a learner activates and endures his cognition, behavior, and feelings that are systematically oriented toward their academic achievement's goal. Then, Santrock (2007) added that an independent learner tends to have realistic learning goals, has the curiosity to develop their knowledge, and has higher motivation. They are also able to control their emotions, monitor their learning progress, and evaluate as well as make needed adaptations to support their achievement.

About teenagers' main concern about their physical appearance, this research focuses on obesity. Obesity is arued to have intense effects on teenager's development. Moreover, obesity is closely related to iron deficiency (Yanoff et al., 2007). Decreased iron may cause reduced adolescent concentration in learning, so it possibly will interfere cognitive function and 
slow down psychomotor development (Lubis, 2008). Also, obese adolescents often feel sleepy and tired easily and may disturb effective learning process.

To sum up, obesity is considered as one of the influential complications in adolescence. It may lead to a variety of cognitive, affective and psychomotor problems, particularly in their learning development. Therefore, it is important to examine how obesity affects adolescent's learning activities, and this study aimed to explore self-regulated learning differences between obese and non-obese adolescents.

\section{A. Self-regulated learning}

Zimmerman (in Woolfolk, 2004) stated that self-regulated learning is a process where a learner initiates and endures his cognition, behavior, and feelings thoroughly to attain learning goals. Zimmerman (in Schunk \& Zimmerman, 1998) separated self-regulated learning into fourteen strategies, namely:

$\begin{array}{ll}\text { 1. } & \text { Self-evaluating } \\ \text { 2. } & \text { Organizing and transforming } \\ \text { 3. } & \text { Goal setting and planning } \\ \text { 4. } & \text { Seeking information } \\ \text { 5. } & \text { Keeping record \& monitoring } \\ \text { 6. } & \text { Environmental structuring } \\ \text { 7. } & \text { Self-consequencing } \\ \text { 8. } & \text { Rehearsing \& memorizing } \\ \text { 9. } & \text { Seek peer assistance } \\ \text { 10. } & \text { Seek teacher assistance } \\ \text { 11. } & \text { Seek adult assistance } \\ \text { 12. } & \text { Review test/work } \\ \text { 13. } & \text { Review notes } \\ \text { 14. } & \text { Review texts book }\end{array}$

\section{Adolescents}

Papalia et al. (2007) stated that adolescents are: "a developmental transition between childhood and adulthood entailing major physical, cognitive, and psychosocial changes." Furthermore, Yusuf (2004) specified that adolescent is a serious developmental stage starts with physical growth, particularly sexual organs that are ready to reproduce. Precisely, Hurlock (2010) detailed that adolescence stages include: (a) early adolescence: age 13-16 /17, (b) late teens: age $16 / 17$ - 18. In this research, the participants were teens in late adolescence phase, ranging from age 16 / 17-18.

\section{B. Obesity}

Sjarif (2002) stated that obesity and overweight are two terms to describe body weight. These two phrases have a different meaning. The word obesity originated from Latin means overeating. However, currently, obesity is termed as an abnormality or illness portrayed by extreme fat accumulation.

WHO (2006) suggested Body Mass Index (BMI) as a typical measurement of obesity. BMI is the simplest technique to assess obesity. The formulation of Body Mass Index is:

$$
\text { BMI }=\frac{\text { Weight }(\mathrm{kg})}{\text { Height }(\mathrm{m}) \mathrm{X} \operatorname{Height}(\mathrm{m})}
$$

\begin{tabular}{|c|c|c|}
\hline \multicolumn{2}{|l|}{ Classification } & BMI \\
\hline THIN & $\begin{array}{l}\text { Underweight } \\
\text { Light } \\
\text { underweight }\end{array}$ & $\begin{array}{l}<17.0 \\
17.0-18.5\end{array}$ \\
\hline NORMAL & $\begin{array}{l}\text { Healthy } \\
\text { weight }\end{array}$ & $18.6-25.0$ \\
\hline \multirow[t]{2}{*}{ OVERWEIGHT } & Overweight & $25.1-27.0$ \\
\hline & Obesity & $>27.0$ \\
\hline
\end{tabular}

\section{METHODS}

This study was a comparative study intended to investigate self-regulated learning differences between obese and non-obese. The participants were 117 obese and 117 non-obese senior high school students in Medan City. The sampling technique used simple random.

\section{RESULTS}

\section{A. Obese Participants}

Based on age, height, body weight, and BMI, obese participants were mostly on 15.99 years old, 1.59 meters height, average body weight was $73.21 \mathrm{~kg}$, and BMI was 29.01. 58 or $49,5 \%$ of them were female, and 59 or $50,5 \%$ were male.

\section{B. Non-Obese Participants}

Also based on age, height, body weight, and BMI. Non-obese students participated in this study were 16.13 years old on average, 1,61 meters height, average body weight was $56,19 \mathrm{~kg}$, and BMI were 21,74 . 67 or $57,2 \%$ of them were female, and 50 or $42,8 \%$ were male.

\section{Self-regulated Learning Differences between Obese and Non-obese Adolescents \\ This study aimed to examine self-regulated learning differences between obese and non- obese adolescent. The data were analyzed by using independent sample t-test. Unexpectedly,}


the result indicated that there were no selfregulated learning differences between obese and non-obese adolescents ( $t=0.673, p>0.05)$.

\section{DISCUSSIONS}

The main result of this study indicated that there were no self-regulated learning differences between obese and non-obese adolescents in Medan City's High School students. This unpredicted result indicated that self-regulated learning might be affected by other variables, such as self-efficacy, motivation, and goals (Cobbs, 2003). The result was somehow in line with Anggraini, et al. (2017) that found that there was no self-concept difference between obese and non-obese high school students in Medan City. This suggests that self-belief, regardless of physical condition, might affect a person's ability to endure a learning process.

Moreover, this unexpected result can also be caused by other factors that occur during the research process. According to Suryabrata (2010), there are some factors that may lead the research could not prove the hypothesis proposed, including theoretical basis, samples, data obtaining, research design, statistical problems, and dependent variables. One of the weaknesses in this study is the use of instruments. This study used self-report to obtain sensitive issues. Therefore, the possibility of social desirability may cause how the respondent answers the questions. According to Salkind (2010), when a study utilize a self-report, the participants tend to choose higher score (faking good). Moreover, unclear items may also cause social desirability.

\section{CONCLUSIONS}

This study concludes that were no self-regulated learning differences between obese and nonobese adolescents in Medan City's High School students.

\section{RECOMMENDATIONS}

Methodological Recommendations

- Further research should focus on social environment influence on self-regulated learning development, since the study showed that self-regulated learning skills were not much influenced by the physical condition, in this case, obesity.

- To obtain more in-depth results, further research is recommended to employ mixed methods techniques by combining quantitative and qualitative methods. It is vital to discover subjects' emotional state and opinions by doing an interview, so other features that can not be gained through quantitative scale may be discovered.

Practical Recommendations

\section{- Parents}

Parents should unconditionally provide positive support to all activities that benefit their teens, especially regarding inspiring the best strategy in learning

- Teenagers

This study revealed that learning process was not affected by the physical condition. The most important aspect is how confidence in learning.

\section{REFERENCES}

[1] Anggraini D, Rola F. Rahmawati A. 2017. Self-Concept Differences between Obese and Normal Weight Adolescents: A Comparative Study of Senior High School Students in Medan City. un published.

[2] Cobb, Robert. 2003. The relationship between self-regulated learning behaviors and academic performance in web-based courses. The Faculty of Virginia polytechnic Institute and State University: Dissertation.

[3] Hurlock. E. B. 2010. Psikologi Perkembangan : Suatu Pendekatan Sepanjang Rentang Kehidupan. (Terjemahan Istiwidayanti \& Soejarwo), Edisi Kelima, Jakarta : Erlangga.

[4] LPTUI Team. 2005. Belajar tentang belajar. www.lptui.com/artikel.php.24 April 2008

Monks, dkk.1999. Psikologi Perkembangan : Pengantar dalam Berbagai Bagiannya. Yogyakarta: Gadjah Mada University.

[6] Lubis, Bidasari. 2008. Pencegahan Anemia Defisiensi Besi Sejak Bayi Sebagai Salah Satu Upaya Optimalisasi Fungsi Kognitif Anak Pada Usia Sekolah. Pidato Pengukuhan Guru Besar Tetap Bidang Ilmu Kesehatan Anak FK USU Medan.

[7] Papalia, Diene E; Olds, Sally Wendoks \& Feldman Ruth Duskin. 2007. Human 
Development (10th edition) USA: Blacklick, Ohio U.S.A.,: Mc Gra Hardcover.

[8] Savira, Fitri \& Suharsono, Yudi. 2013. Prokrastinasi Akademik pada Siswa Akselerasi. Jurnal Ilmiah Psikologi Terapan. Vol 01. No. 01 Januari 2013

[9] Savitri, Indri. 2008. Arti Belajar Penting Ditanamkan Pada Anak Usia Sekolah. http://www.lptui.com/artikel.php?fl3nc= 1\&param $=$ c3VpZD0w MDAyMD AwMDAwNzY\%3d\&cmd=articleDetail. 24 April 2008

[10] Salkind, Neil J. (2010). Encyclopedia of Research Design. The University of Kansas USA. Sage Publication Inc.

[11] Santrock, J. W., (2013). Life - Span Development (10th ed) Boston, Mc. Graw. Hill, Inc

[12] -----------, (2004). Psikologi Pendidikan, edisi kedua. Kencana Prenada Media Group : Jakarta.

[13] Sjarif, Damayanti R.(2002). Obesitas pada anak dan permasalahannya. Dalam Pratini P Trihaho, Purnawati, Damayanti, Baidul Hartono, Hanifah dan Mauzal Kadim. Hot
Topics in Pediatics II. Jakarta : Balai Penerbit UI.

[14] Suryabrata, Sumadi.2010.Metodologi Penelitian.Jakarta: PT. Raja Grafindo Persada

[15] Woolfolk, A. (2004). Educational psychology ( $9^{\text {th }}$ ed). Boston MA Ellyn and Bacon.

[16] Yanoff et al., (2007). Inflammation and iron deficiency in the hypoferremia of obesity. International Journal Obesity. Publishes online 2007.

[17] Yusuf, Syamsu (2004). Psikologi Perkembangan Anak dan Remaja. Bandung: PT. Remaja Rosdakarya

[18] Zimmerman, BJ. (1989). A Social-cognitive view of self-regulated learning. Journal of Educational Psychology, 81.329-339.

[19] Zimmerman, B.J. \& Schunk, D.H. (Eds). (2001). Self-regulated learning and academic achievement. Mahwah, NJ: Erlbaum. [On-line]. Available FTP: http://www.questia.com/ PM.qst?A $=0 \& \mathrm{~d}=77009710 . \mathrm{html}$. Tanggal akses 10 April 